\title{
Social Interaction and Creative Thinking Skills to Influence Students' Conceptual Understanding on Optical Geometry
}

\author{
Meji Aprianingtyas ${ }^{1 *}$, Widha Sunarno ${ }^{1}$, Suparmi Suparmi²
}

\begin{tabular}{l} 
ARTICLE INFO \\
\hline Article History: \\
Received 05.04 .2019 \\
Received in revised \\
form 06.09 .2019 \\
Accepted \\
Available online \\
01.11.2019
\end{tabular}

\begin{abstract}
The aim of this research was to determine the influence of learning physics using project and experimental methods in terms of social interaction and creative thinking of students. The learning material used is about optical devices. The results of the study include: (1) Students are not fluent in providing answers; (2) Students are less able to think openly in answering questions; (3) When the teacher gives questions, students do not immediately take the initiative to answer; (4) Students tend to answer questions whose answers are already listed in the textbook; (5) Students give examples according to what the teacher gave; (6) Students are less able to combine information that has been given by the teacher to provide examples or other answers to a question; (7) Students are less able to give ideas about a thing with several different points of view; (8) Students are less able to create their own ideas that are new and different from usual. The results of students' conceptual understanding on optical geometry can be placed into pattern and be influenced by social interaction and creative thinking skills.
\end{abstract}

(C) IJERE. All rights reserved

Keywords:

Social Interaction, Creative Thinking Skills, Optical Geometry

\section{INTRODUCTION}

Education is a means to improve the quality of a nation, the quality of a nation can be measured based on the progress of education (Pasi Sahlberg 2007). Good quality education is the quality of education that can improve the quality of human resources so as to increase the success of a nation (Robert B. Barr \& John Tagg 1995). Improving the quality of education depends on the quality of teachers, curriculum, leadership of the school principal and infrastructure (Duman,T. \& Karagoz, 2016; Kaya, 2018; Kenneth Leithwood, Alma Harris \& David Hopkins 2008). Education aims to explore the individual's potential by understanding and completing what is being faced through a learning process. The learning process at school is part of the formal education process used to provide students' learning experiences, one of which is by using learning approaches and strategies.

Effective learning that is if in learning two-way interaction occurs between the teacher and students, meaning that the teacher does not have to be the dominant party (Michael Simonson, Charles Schlosser \& Dan Hanson 1999). Where in this learning the teacher is not only as a provider of information but also the teacher must be able to be responsible as an implementer who must create a situation of leading, stimulating, and actively moving students. In addition students should also dare to express opinions, ask questions and issue ideas. The change of a teacher from an informant to a learning manager that aims to teach students to be active so that changes in behavior occur in accordance with the learning objectives (Mahnaz Moallem 1998).

In the 2013 curriculum the learning approach applied is a scientific (scientific) approach for all levels (Donovan A. McFarlane 2013). In this learning approach includes: digging information through observation, asking, trying, then processing data or information, presenting data or information, followed by analyzing,

\footnotetext{
${ }^{1}$ mejiaprianingtyas@gmail.com,orcid.org/0000-0001-9041-6365, Sebelas Maret University Indonesia

${ }^{2}$ widhasunarno@gmail.com, orcid.org/0000-0001-8264-3509, Sebelas Maret University Indonesia

${ }^{3}$ suparmiuns@gmail.com, orcid.org/0000-0001-8395-4309, Sebelas Maret University Indonesia
} 
Aprianingtyas,M., Sunarno W. \& Suparmi,S. (2019). Social interaction and creative thinking skills to influence students' conceptual understanding on optical geometry. International Journal of Educational Research Review, Special Issue, 701-710.

reasoning then concluding, and creating and forming networks. The learning process using this scientific approach touches three domains, namely attitude (affective), knowledge (cognitive), and skills (psychomotor) (Punia Turiman 2012).

Physics learning in schools will bring students to find a concept based on experimental and observational activities. Students are usually also required not only to be able to master the concepts of physics in theory alone, but also are required to understand and be able to solve problems using mathematical formulas (Lillian C. McDermott 1990). Scientific-based physics learning aims to provide an introduction and understanding to students by using a scientific approach, one of which is by the application of practicum systems in learning. Thus, information about physical material obtained not only comes from the teacher, but students can obtain their own information through observations they do. Learning using this scientific basis must be supported by using other methods, such as the experimental and project methods.

The ability to think creatively belongs to everyone because humans are creative creatures. A creative process is a thought process that can solve problems in Hebert's original and useful way (Rawlinson: 1979). Munandar (2004) states that there are several characteristics of creative thinking according to Guilford namely fluency, flexibility (originality), elaboration (Elaboration). In recent years there has also been increasing pressure on teachers to support the development of 21st century abilities such as communication, problem solving, and creativity (Wagner, 2010; Robinson, 2011 in Richardson, 2018). Creativity is one component in the ability to think that is realized as an important feature for developing countries like Indonesia. The ability to think creatively is very important in learning activities to improve the ability to think higher in solving problems in learning physics (Armandita et al., 2017).

Social interaction and students' creative thinking abilities influence student learning outcomes. Based on Tori's (2015) research, there is a significant influence between social interaction and student learning outcomes. Creative thinking abilities also affect student learning outcomes (Wahyuni, 2018). Besides the learning methods used by teachers also affect student learning outcomes. According to Nur M's research (2012) there is an effect of the application of experimental methods on physics learning on student learning outcomes. According to the research of Heni R (2016) learning using the project method provides increased student learning outcomes.

Based on the results of the pre-research stage using needs analysis and interviews with teachers and students, students want interesting and fun learning, such as the existence of experimental learning methods and projects, in addition to the skills gained through observing, asking, trying, associating and communicating activities can encourage participants students to make observations to the creation to improve students' creative thinking abilities (Xu, M. A., \& Storr, G. B. 2012).. When the teaching and learning process takes place using the experimental and project methods, good social interactions between students and teachers will be realized.

The various reasons that arise are irrelevant to the expected physics learning. Teachers can develop and apply various learning methods or strategies with reference to the characteristics of students to empower their creative thinking abilities and social interaction between students(Lilia Bartolomé 1994). Students should improve their ability to think creatively by always practicing to solve a problem with various alternative answers. The training of a student to solve problems with various alternatives will make the way of thinking of students better.

From the background of the problems above, the authors are interested in research on learning physicsbased physics using project and experimental methods in terms of social interaction and creative thinking of students. The learning material used is about optical devices. 


\section{METHOD}

This research is a quantitative descriptive study using the test method. The test method was chosen to describe the percentage of students' creative thinking skills in one of the state high schools in Surakarta. This study uses a purposive sampling technique based on class categorization (low and high categories). Data collection techniques or assessment instruments used in this study were in the form of test instruments for students' creative thinking abilities that had been prepared based on indicators of creative thinking abilities. The students work on the tests given by researchers to analyze students' creative thinking abilities, especially for optical devices, using indicators of creative thinking skills. For open-ended question scores, this study uses rubrics that have been validated by experts for each indicator. Data on test results were analyzed with descriptive percentages. The level of development of students' creative thinking abilities is measured by looking for percentages.

Students are given tests to analyze their creative thinking skills, especially in science learning. The test uses a multiple choice form with the type of open-ended questions based on creative thinking indicators previously validated by a team of learning evaluation experts and item validity testing using the Karl Person product moment correlation coefficient formula, reliability testing using Alpha formula, differentiation test and test difficulty level. The science topics in the problem include the phenomena of daily life. Scoring of multiple-choice open-ended questions uses rubrics that have been validated by experts of each indicator( Anders Jonsson Gunilla Svingby 2007).

The data obtained in the form of creative thinking skills results are processed by calculating the percentage of scores obtained by students on each indicator of creative thinking abilities then the percentage is interpreted according to the criteria of the level of creative thinking abilities Burch T. (Kealey, Jonna Holland, and Marsha Watson 2005). The sample of this study was class XI IPA 1 and XI IPA 2 in one of the senior high schools in Surakarta. the total sample was 59 students, 23 male students and 36 female students. Category of students' creative thinking skills can be seen in Table 1.

Table 1. Category of creative thinking skills adopted from Shriki

\begin{tabular}{cl}
$6 \mathrm{pt}$ & \\
\hline Percentage & Category \\
\hline$<55 \%$ & Low \\
$\leq 55 \%-<75 \%$ & Medium \\
$\geq 75 \%$ & High \\
\hline
\end{tabular}

The data obtained in the form of social interaction results are processed by calculating the percentage of scores obtained by students on each indicator of social interaction then the percentage is interpreted according to the criteria of the level of social interaction. Category of students' social interaction can be seen in Table 2.

Table 2. Category of social interaction skills adopted from Kelley

\begin{tabular}{ll}
$6 \mathrm{pt}$ & \\
\hline Percentage & Category \\
\hline
\end{tabular}


Aprianingtyas,M., Sunarno W. \& Suparmi,S. (2019). Social interaction and creative thinking skills to influence students' conceptual understanding on optical geometry. International Journal of Educational Research Review, Special Issue, 701-710.

\begin{tabular}{cl}
\hline$<40 \%$ & Low \\
$\leq 40 \%-<80 \%$ & Medium \\
$\geq 80 \%$ & High \\
\hline
\end{tabular}

\section{RESULT, DISCUSSION, AND SUGGESTIONS}

In this study there are three variables, namely the independent variable, moderator variable, and the dependent variable. The independent variable is scientific-based physics learning using experimental and project methods. The moderating variables are students 'social interactions and students' creative thinking abilities. The dependent variable is student physics learning outcomes in aspects of knowledge, attitudes, and skills. Data in this study include data on students' initial abilities, data before learning, and data after learning. Students' initial ability data is used to select samples from both classes that have equivalent or equal initial abilities.

\subsection{Students' social interaction}

Data on students' social interactions were obtained through filling in the observation sheet by the observer which was conducted before the research took place with the help of the physics teacher in the class used as a sample.

Table 3. Students' social interaction skills.

\begin{tabular}{lccccc}
\hline \multicolumn{1}{c}{ Class } & $\mathrm{N}$ & Max & Min & St Dev & Mean \\
\hline Experiment & 29 & 11 & 13 & 0.673 & 12.103 \\
Project & 30 & 23 & 21 & 0.691 & 22.067 \\
\hline
\end{tabular}

In Table 3, it can be seen that the average social interaction value of the experimental class and project class students is 12.103 and 22.067, and the combined average value is 17.170 . Based on the combined values of the two classes, the social interaction of students was categorized for the experimental class and the project class into three categories namely high, medium and low. Students have a high category if the value obtained $(\mathrm{X})>$ $+\mathrm{SD}$, while if the value obtained is in the range M-SD $<(X)<M+S D$, and low if the value obtained $(X)<M-$ SD. Distribution of social interaction data of students in the experimental class and project class is presented in Table 4.

Table 4. Category of students' social interaction skills.

\begin{tabular}{ccccc}
\hline Category & \multicolumn{2}{c}{ Project } & \multicolumn{2}{c}{ Experiment } \\
\cline { 2 - 5 } & $\mathrm{n}$ & $\mathrm{f}$ & $\mathrm{n}$ & $\mathrm{f}$ \\
\hline High & 3 & $10 \%$ & 5 & $17 \%$ \\
\hline
\end{tabular}


Aprianingtyas,M., Sunarno W. \& Suparmi,S. (2019). Social interaction and creative thinking skills to influence students' conceptual understanding on optical geometry. International Journal of Educational Research Review, Special Issue, 701-710.

\begin{tabular}{ccccc}
\hline Medium & 13 & $43 \%$ & 16 & $55 \%$ \\
\hline Low & 14 & $47 \%$ & 8 & $28 \%$ \\
\hline
\end{tabular}

In Table 4, it can be seen that the average experimental class and project class students have social interactions in the medium category. In the project class there are 10\% students in the high category, $43 \%$ students in the medium category, and $47 \%$ students in the low category. In the experimental class there were $17 \%$ of students in the high category, $55 \%$ of students in the medium category, and $28 \%$ of students in the low category.

\subsection{Students' creative thinking skills}

The data of students' creative thinking skills were obtained through filling in the observation sheet by the observer which was carried out before the research took place with the help of the physics teacher in the class used as a sample.

Table 5. Students' creative thinking skills.

\begin{tabular}{lccccc}
\hline \multicolumn{1}{c}{ Class } & N & Max & Min & St Dev & Mean \\
\hline Experiment & 29 & 11 & 13 & 0.673 & 12.103 \\
Project & 30 & 23 & 21 & 0.691 & 22.067 \\
\hline
\end{tabular}

In Table 5, it can be seen that the average value of the creative thinking ability of the experimental class and project class students is 12.206 and 21.967, and the combined average value is 17.170. Based on the combined values of the two classes, the students' creative thinking abilities for the experimental class and project class were categorized into three categories: high, medium, and low. Students have a high category if the value obtained $(X)>+S D$, while if the value obtained is in the range $M-S D<(X)<M+S D$, and low if the value obtained $(X)<-$ SD. Distribution of social interaction data of experimental class students and project classes is presented in Table 6.

Table 6. Category of students' creative thinking skills.

\begin{tabular}{ccccc}
\hline Category & \multicolumn{2}{c}{ Project } & \multicolumn{2}{c}{ Experiment } \\
\cline { 2 - 5 } & $\mathrm{n}$ & $\mathrm{f}$ & $\mathrm{n}$ & $\mathrm{f}$ \\
\hline High & 3 & $10 \%$ & 5 & $17 \%$ \\
\hline Medium & 13 & $43 \%$ & 16 & $55 \%$ \\
\hline Low & 14 & $47 \%$ & 8 & $28 \%$ \\
\hline
\end{tabular}

In Table 6, it can be seen that the average experimental class and project class students have the ability to think creatively in the medium category. In the project class, there were $19 \%$ of students in the high category, 
Aprianingtyas,M., Sunarno W. \& Suparmi,S. (2019). Social interaction and creative thinking skills to influence students' conceptual understanding on optical geometry. International Journal of Educational Research Review, Special Issue, 701-710.

$56 \%$ of students in the medium category, and $25 \%$ of students in the low category. In the experimental class there were $28 \%$ of students in the high category, $47 \%$ of students in the medium category, and $25 \%$ of students in the low category.

\subsection{Students' conceptual understanding on optical geometry}

ANAVA test analysis results are carried out to test the hypothesis based on this research that is to find out the differences in learning outcomes of students who are given learning by scientific models using experimental methods and project methods. It is taken to also know the differences in learning outcomes between students who have high character, medium character and low character, know the difference learning outcomes of students who have high creative thinking abilities, medium creative thinking abilities and low creative thinking abilities, know the interaction of influence between scientific learning using the experimental method and project methods with student characters on student learning outcomes.

Knowing the interaction of influence between scientific learning using experimental methods and project methods with students' creative thinking abilities on student learning outcomes, knowing the interaction of influence between student characters and creative thinking abilities on student learning outcomes, knowing the interaction between the scientific learning method uses the experimental method and the project method with the character and the ability of students' creative thinking towards student learning outcomes. The mean student learning outcomes in the group of students who were given scientific learning accompanied by the experimental method by 66.81 while the mean student learning outcomes in the group of students who were given scientific learning accompanied by the project method by 71.19. This shows that the learning of scientific learning with the project method produces better student learning outcomes than scientific learning with experimental methods. This is because in learning scientific learning with the project method, the teacher gives freedom of thought to students to understand the concepts to be learned either through face to face or online. This is evidenced through the student worksheets on the project method requires more students to think actively such as planning experiments starting from planning experiments and experimental steps, data analysis activities ranging from making tables of experimental results and experimental charts. This makes students better understand the concept because the learning process makes students to learn actively by finding their own concept well through the method.

The learning process of scientific learning using the project method is different from scientific learning using the experimental method even though the two learning together combine learning face to face and online. In scientific learning with the experimental method, students conduct experiments according to the guidelines that have been prepared by the teacher so that students' freedom of thought in solving problems has not been maximally emphasized. This is because the experimental method emphasizes the direct involvement of students to conduct experiments in order to prove a hypothesis to get a concept. In addition, scientific learning using the experimental method emphasizes the teacher to participate in guiding and guiding students in carrying out the steps in each experiment. This is based on student worksheets on the experimental method already containing the experiment plan, the results of the experiment table, and the results of the experiment graph.

Research that proves that the project method is better than the experimental method has also taken place in previous studies. Purwandari et al (2017) states that the learning outcomes of knowledge in the project method are greater than the experimental method. This is because students experience the process of scientific discovery directly so that learning takes place effectively. This is also supported by Saputri et al (2013) which states that the cognitive learning achievement of students given the project method is greater than the cognitive learning achievement of students who are given the experimental method. This is because the project method motivates students' desire to learn while they are trying to understand physics concepts (Sola et al, 2007). Figure 1 showed students' answer sheet to concave mirror drawing using special rays. 


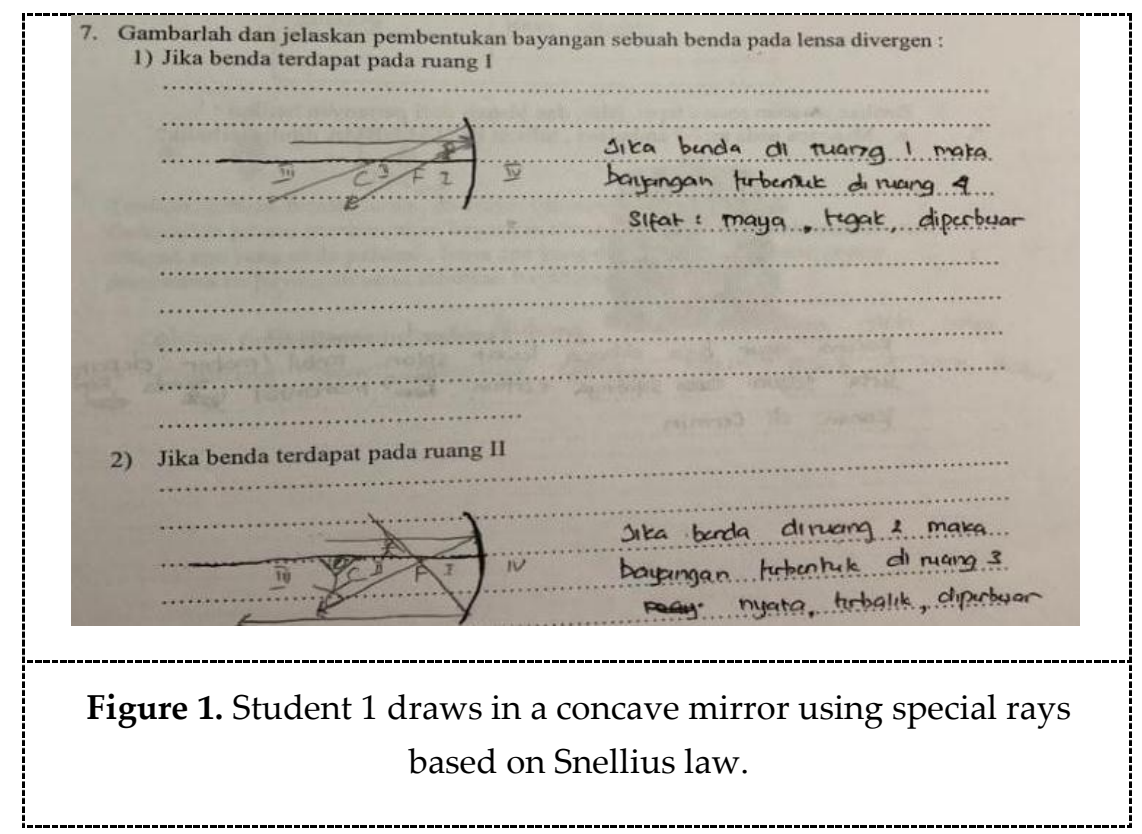

Students who have social interaction tends to draw the rays properly and students who have low social interaction draw the rays incorrectly. Thus the results of students' conceptual understanding on optical geometry can be placed into pattern and be influenced by social interaction.

The mean student learning outcomes in the group of students who have high social interaction by 78.63 , the average student learning outcomes in the group of students who have moderate social interaction by 70.58 , the average learning outcomes of students in the group of students who have low social interaction by 57.11. This shows that social interaction influences students' cognitive learning achievement. social interactions used in this study are cooperation, tolerance, competition, conflict, and communication. social interaction is very needed by students to take action in accordance with scientific and participatory methods. This is inseparable from the nature of physics which is one branch of natural science that studies about natural phenomena and is able to solve the problems of natural phenomena with scientific methods.

Social interaction is a character that can improve student cognitive learning achievement. This is because students who have high social interaction have a tendency to be curious about a problem and carry out a series of creative and structured activities to solve the problem through scientific steps. This is supported by previous studies of Rohmani et al (2015) showing that students with high social interaction have better learning achievement than students who have low social interaction. This is also supported by Wahyudi (2016) who states that the characters have a positive and significant relationship to student learning outcomes, so it can be concluded that the higher the social interaction of students, the higher the learning outcomes of students' knowledge. 


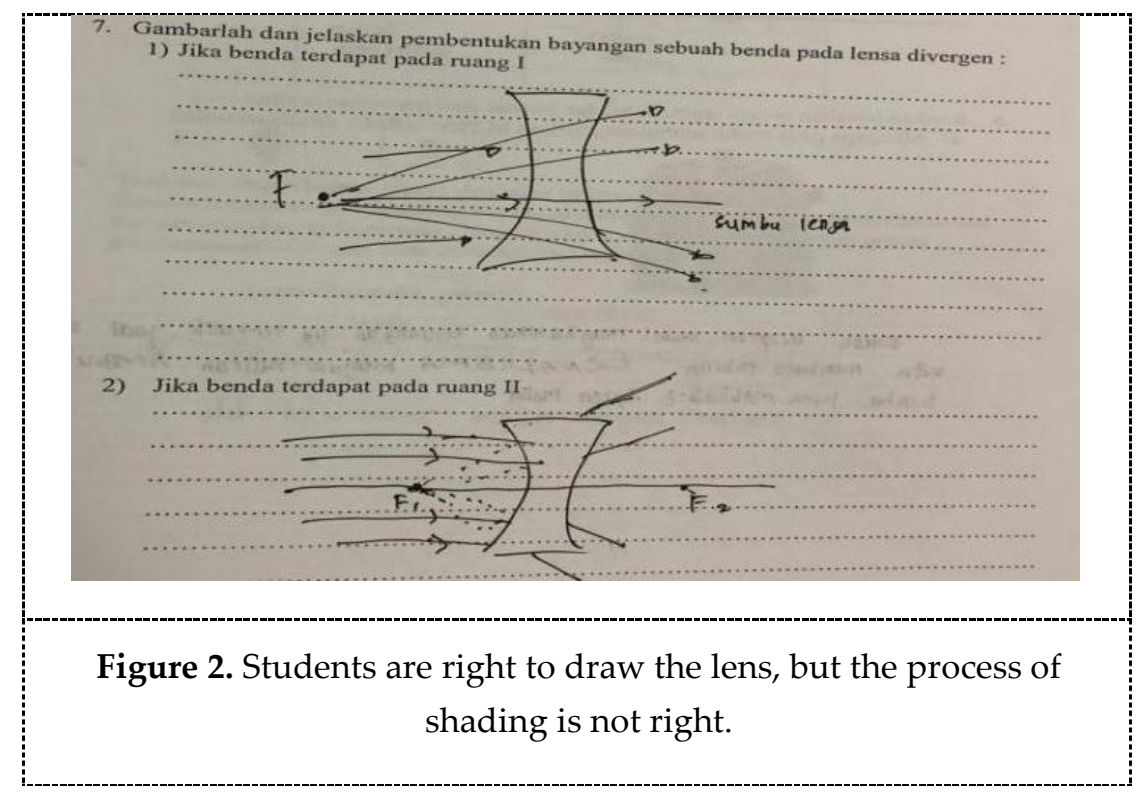

Students who have high creative thinking skills tends to draw the rays properly and students who have low creative thinking skills draw the rays incorrectly. Thus the results of students' conceptual understanding on optical geometry can be placed into pattern and be influenced by creative thinking skills. So, it can be concluded that social interaction and creative thinking skills can influence students' conceptual understanding on several optical geometry concepts.

Based on these results, they indicate that the way of thinking students are not optimally trained to think creatively. Therefore, it is important to empower creative thinking in learning, especially in science subjects given its strategic value. In contrary, the percentage of achievement of students' conceptual understanding influenced by social interaction and creative thinking skills that is very far from the target is originality indicator. Based on these results indicated, there is a result that the way students think have not been optimally trained, especially when they are asked to think creatively and asked to have good social interaction. Therefore, it is important to empower creative thinking skills in learning, especially in natural science subjects as it has been given the strategic value.

\section{CONCLUSION}

In general, the results of the study include: (1) Students are not fluent in providing answers; (2) Students are less able to think openly in answering questions; (3) When the teacher gives questions, students do not immediately take the initiative to answer; (4) Students tend to answer questions whose answers are already listed in the textbook; (5) Students give examples according to what the teacher gave; (6) Students are less able to combine information that has been given by the teacher to provide examples or other answers to a question about optical geometry; (7) Students are less able to give ideas about a thing with several different points of view in understanding on optical geometry; (8) Students are less able to create their own ideas that are new and different from usual. The results of students' conceptual understanding on optical geometry can be placed into pattern and be influenced by social interaction and creative thinking skills. So, students need to improve their two skills to have better conceptual understanding on several concepts of optical geometry in senior high schools. Supported by learning methods used by teachers.

\section{ACKNOWLEDGMENTS}

Authors wishing to acknowledge assistance or encouragement from colleagues from Sebelas Maret University and husband and family who give a lot of support since the beginning. Authors also thank to any included people who help this research done properly. 


\section{REFERENCES}

Anwar, M. N., Shamim-ur-Rasool, S. \& Haq, R. (2012). A comparasion of creative thinking abilities of high and low achievevers secondary school student. International Interdisciplinary Journal of Education, 1 (1).

Barr,R.B. \& John Tagg,J. (1995) From teaching to learning - a new paradigm for undergraduate education, change. The Magazine of Higher Learning, 27:6, 12-26, DOI: 10.1080/00091383.1995.10544672

Bartolomé,L. (1994) Beyond the methods fetish: Toward a humanizing pedagogy. Harvard Educational Review: 64(2),173-195.

Dariyanto (2009). Panduan Proses Belajar Kreatif dan Inovatif (Jakarta: Buku yang Cerdas dan Mencerdaskan). Duman,T. \& Karagoz,S. (2016). An evaluation of Turkish teacher education system compared to other models in different countries. International Journal of Educational Research Review , 1 (1), 1-13.

Freudenberg, B., Brimble, M. \& Cameron, C. (2011). Work-integrated learning and generic skill development: The development of business students' generic skills through work-integrated learning. Asia-Pacific Journal of Cooperative Education, 12 (2),79-93.

Guilford, J. P. (1975) Varieties of creative giftedness, their measurement and development. Gifted Child Quaterly,19,107-21.

Heilman, G. \& Korte, W. B. (2010) The role of creativity and innovation in school curricula in the Eu2 (Luxembourg: Publications Office of the European Union).

Jonsson,A. \& Svingby,G. (2007). The use of scoring rubrics: Reliability, validity and educational consequences. Educational Research Review, 2(2), 130-144.

Kampylis, P. \& Berki, E. (2014). Nurturing creative thinking (Belle France: UNESCO).

Kaya, İ.(2018). Examination of preschool teachers' opinion on alternative assessment. Universal Journal of Educational Research 6 (10), 2294-2299.

Kealey,B.T., Holland,J. \& Watson,M. (2005) Preliminary evidence on the association between critical thinking and performance in principles of accounting. Issues in Accounting Education, 20 (1),33-49.

King, F. J., Goodson, L. \& Rohani, F. (2009). Higher order thinking skills in publication of the educational services program, now known as the center for advancement of learning and assessment. Retrieved from http://www.cala.fsu.edu/files/higher_order_thinking_skills.pdf (online).

Kumar, J. (2014). A study of creative thinking abilities of senior secondary school student in realation to their intelegence. Scholarly Research Journal For Humanity Science \& English Languange 1 (1).

Leithwood,K., Harris,A. \& Hopkins,D. (2008) Seven strong claims about successful school leadership, School Leadership \& Management, 28:1, 27-42, DOI: 10.1080/13632430701800060 .

Massoudil, M. (2003) Can scientific writing be creative? Journal of Science Education and Technology, 12,115-28

McDermott,L.C. (1990). A perspective on teacher preparation in physics and other sciences: The need for special science courses for teachers. American Journal of Physics 58, 734 https://doi.org/10.1119/1.16395

McFarlane,D.A. (2013) Understanding the challenges of science education in the 21st century: New opportunities for scientific literacy. International Letters of Social And Humanistic Sciences, 10,35-44.

Pahlevi,T., Rosy,B. \& Ranu,E.M. (2018). A scientific approach based on portfolio assessment for autonomy problem solving. International Journal of Educational Research Review,3 (2), 29-36.

Purwanti,D., Gunarhadi \& Musadad,A.A. (2019). The effect of local-based 2013 curriculum implementation on students' environmental awareness. International Journal of Educational Research Review,4(1),65-75.

Rofi'udin, A. (2000) Model Pendidikan Berpikir Kritis Kreatif untuk Siswa Sekolah Dasar (Majalah Bahasa dan Seni) 1 (28) pp 72-94. 
Aprianingtyas,M., Sunarno W. \& Suparmi,S. (2019). Social interaction and creative thinking skills to influence students' conceptual understanding on optical geometry. International Journal of Educational Research Review, Special Issue, 701-710.

Sahlberg,P. (2007) Education policies for raising student learning: The Finnish approach. Journal of Education Policy, 22:2, 147-171, DOI: 10.1080/02680930601158919.

Simonson,M., Schlosser,C. \& Hanson,D. (1999) Theory and distance education: A new discussion, American Journal of Distance Education, 13:1, 60-75, DOI: 10.1080/08923649909527014

Siswono, T. Y. E. (2008) Model Pembelajaran Matematika Berbasis Pengajuan dan Pemecahan Masalah untuk Meningkatkan Kemampuan Berpikir Kreatif (Surabaya: Universitas Negeri Surabaya)

Turiman,P. Omar,J. Daud,A.M. \& Osman,K. (2012). Fostering the 21 ${ }^{\text {st }}$ Century Skills through Scientific Literacy and Science Process Skills. Procedia - Social and Behavioral Sciences, 59 ,110-116.

Udi, E. A. \& Amit, M. (2011) Developing the skills of critical and creative thinking by probability teaching. Procedia Social and Behavioral Sciences, $15,1087-91$

Xu, M. A., \& Storr, G. B. (2012). Learning the concept of researcher as instrument in qualitative research. The Qualitative Report, 17(21), 1-18. 